ADDIN, Volume 11, Number 1, February 2017

\title{
STRENGTHENING BHINNEKA
}

TUNGGAL IKA AS AN IDENTITY AND

UNIFIER OF THE NATION:

Realizing A Peaceful Islam And Statehood

Harmonization

\section{Egi Sukma Baihaki}

Sekolah Tinggi Filsafat Islam (STFI) Sadra Jakarta, Indonesia

egisukma_baihaki@yahoo.com

\section{Abstract}

The development of the word and the rise of acts such as the destruction of worship houses disputes between religious communities and the acts of terrorism can harm the social order that has been well tied by Bhinneka Tunggal Ika. Thus, understanding about "Bhinneka Tunggal Ika" is an important thing to be concerned and maintained by all elements of the nation. Because the diversity that has existed in Indonesia is a noble heritage deposited by the predecessors to be continued and maintained. Strengthening Bhinneka Tunggal Ika will be needed to reinforce the identity of Indonesia, and become a unifying media for any different faction to unite and to create the peaceful, secure, and prosperous life.

Keyword: Bhinneka Tunggal Ika, Diversity, Sunnatullah, Difference, Humanity, Solidarity. 


\section{Abstrak}

Perkembangan kata dan munculnya tindakan seperti perusakan sengketa rumah ibadah antar umat beragama, dan aksi terorisme dapat membahayakan tatanan sosial yang telah diikat erat oleb Bbinneka Tunggal Ika. Oleh karena itu, memahami tentang "Bhinneka Tunggal Ika” adalah suatu hal yang penting untuk dipelajari dan dipelibara oleh semua elemen bangsa. Sebab, keragaman yang telab ada di Indonesia merupakan warisan mulia yang dititipkan oleh para pendabulu untuk terus dijaga dan dipertahankan. Penguatan Bhinneka Tunggal Ika akan diperlukan untuk memperkuat identitas bangsa Indonesia dan menjadi media pemersatu bagi setiap faksi yang berbeda dan menciptakan kehidupan yang damai, aman, dan sejabtera.

Kata Kunci: Bhinneka Tunggal Ika, Keanekaragaman, Sunnatullah, Perbedaan, Kemanusiaan, Solidaritas.

\section{A. Introduction}

By the geographical conditions which are very spacious and outstretched several islands from Sabang to Merauke, not only make Indonesia become rich by the natural resources which are abundant and able to attract by the eyes. Indonesia also has a human resources that were very supportive and spread in some areas with large numbers include some aspects of language, race, culture, and religion. Many things are owned by Indonesia that has created a culture of compound life. That condition has existed since long time ago and has been tied with a slogan that unites the vision of all elements of society in the bond of nationality through Bhinneka Tunggal Ika. By this slogan, we are from different regions that existed before independence, with a variety of language, culture, race, ethnicity and religion expressed our vision to unite into a state that called Indonesia. 
The diversity and plurality are a gift that needs to be maintained by all elements of the society and the government. Because of this gift is vulnerable under attack by both internal and external. The right understanding of Bhinneka Tunggal Ika will affect the people's behavior in their daily lives, whether in words or action. As the slogan which became a tie that binds all the diversity, make Bhinneka Tunggal Ika must be maintained and concerned by all elements of the nation. Nevertheless, there is no doubt that the condition of the peace and harmony of mutual respect in society and state, sometimes are damaged by the actions and attitudes that seek even have tarnished the value of diversity that has existed. Such actions include the emergence of terror acts and other forms of religious radicalism. In fact, the attitude of the ego which sometimes appears in personal society which related to religion issue, sometimes create heat friction which is able to break the unity. Just because the issue of religion and feel as the majority then threw criticism over the inclusion of the hero in the new rupiah currency just because of difference in religion of a hero. ${ }^{1}$

The case is a small sample of the factors which still lack of understanding nationality held by the public. Because of different views and the way to find it to be the strongest and most, and then tried to suppress the weak. The term of majority and the minority always are used to legislate where the strong group and which groups are weak, where the ruling group and deserves to be given more care, and which do not have power and had to get a makeshift facilities. The differences have raised barriers in public life, including in the social aspect. Unity which has been guarded and coveted

${ }^{1}$ Related to this case can be seen, http://m.tribunnews. com/nasional /2016/12/25/ menyedihkan-netizen-lecehkan-pahlawan-nasional-dari-papua-inilahjasa-besarnya-untuk-indonesia, accessed 15 Januari 2017. 
could eventually just become a dream with egos who want to show their existence.

\section{B. Discussion}

\section{History and Meaning Bhinneka Tunggal Ika}

Bhinneka Tunggal Ika itself is derived from the Ancient Javanese phrase, which translates as "berbeda-beda tetapi tetap satu jua". Besides it contained in our emblem, Garuda Pancasila, the motto of our country is also mentioned in the ' 45 Constitution. Bhinneka Tunggal Ika is quoted from poem Kakawin Sutasoma written by Mpu Tantular during the rule of the Majapahit kingdom, around the 14 th century. ${ }^{2}$ Through this slogan, the whole different society can unite the vision and mission to become a family who protect, maintain, respect, and appreciate each others. Because of their shared causes, then through Bhinneka Tunggal Ika in order that the life of Indonesian society becomes more focused, and the differences that exist have been considered as part of the forms of diversity. ${ }^{3}$

\section{Understanding Human Diversity}

In the perspective of Islam, the diversity is sunnatullah, the laws of nature that has been appointed by God. Therefore, there is no one person or any group could ignore it. Through the diversity, integrity of willpower builds a life

\footnotetext{
${ }^{2}$ Jimmy B. Oentoro, Indonesia Satu, Indonesia Beda, Indonesia Bisa (Jakarta: Gramedia Pustaka Utama, 2010), p. 9.

${ }^{3}$ We realize that Indonesian society is composed of various ethnic groups (more than 500 ethnic) who have diverse customs, language, culture, religion, belief and trust. In conditions like this plurality, Indonesian society has ever been in the long term experienced Dutch colonial rule, feel kinship than determined to expel the invaders from Indonesia. By the spirit of togetherness and being Indonesian and fight for the independence of the Republic of Indonesia. The fusion of thoughts about the importance of unity, the vision and the desire independence, make Indonesian people become unite in diversity. Bedjo Sujanto, Pemahaman Kembali Makna Bbinneka Tunggal Ika Persaudaraan dalam Kemajemukan (Jakarta: Sagung Seto, 2007), p. 2.
} 
enforced. At the same time, no one and no group has the right to reject the laws of God. Moreover, try it. Human task is to put it all in the frame of the noble values of religion so that justice, equality, and prosperity become a reality that can be reached by every nation and all mankind. ${ }^{4}$

Indeed, creation has a consequence to spawn the diversity. That is evidenced by the creation of the universe which in actual fact is diverse. Diversity is a sunnatullah or a necessity, including in human creation. Humans have diversity whether inherent aspect in human nature itself as in physical terms has differences (kind of eyes, hair, skin, tongue, nose shape, the shape of the lips, eyebrows, nail shape, their feathers around the body, etc.), emotional state, and the differences in language, ethnicity, race, and religion.

Although different, we need to realize that we are all brothers. We come from the same lineage is from Adam and Eve. Despite this turnaround time separates all human and make each one to choose to live in accordance with their line groove destiny and desire, we must grasp the principle of brotherhood continued. Therefore, diversity should not be a reason for us against each other. But the difference and diversity that exists to make us more understanding of each other. In fact, by the diversity we can begin to implement the overlap each other which certainly has the advantages and disadvantages. The Qur'an itself gives an idea that the creation of human variety has a purpose for humans to know each other. ${ }^{5}$

Pluralism has taught mankind to achieve a peace as a whole (Q.S. al-Baqarah [2]: 208). The basic concept of the Qur'an about peace becomes the main reference in

${ }^{4}$ Muchlis M. Hanafi (ed.), al-Qur'an dan Kebbinnekaan (Tafsir al-Qur'an Tematik.) (Jakarta: Lajnah Pentashih Mushaf al-Qur'an, 2011), p. 64.

${ }^{5}$ Q.S. al-Hujurat [49]: 13. 
implementing Islamic teachings of peace and tolerance has been exemplified by the Prophet Muhammad when Islam ruled Medina by treating well other religions even though the Prophet when he was in Makkah often get harsh treatment from the polytheists of Makkah. In fact, Prophet Muhammad made a constitution as formal rules, called the Constitution of Medina, which is a document prepared by the Prophet Muhammad which contains a formal agreement between himself and all the tribes and magnifying Medina in $622 \mathrm{AD}$ with the aim of uniting the people of Medina which consist consisting of various ethnicities and religions. ${ }^{6}$

\section{Realizing Unity and Brotherhood}

In a society that immature psycho-emotionally, the difference is too often perceived as hostility. Though the power which ever spawned great civilizations were encouraged by differences in viewing things. Friction opinion if be discussed as adults will create the formulation of the stronger views and comprehensive. People should not feel that they are always on the most correct, before the opinion was tested through the right dialogue in a tolerance atmosphere and extroverted. ${ }^{7}$ Time by time always there is a conflict in the midst of human life. Social conflicts are not uncommon causing of violence and threatening peace. Although the conflict is an indispensable part of life, but human beings can not survive in a continuous conflicts and disputes. Humans undoubtedly try to avoid conflict and resolve it and find a way out of it. ${ }^{8}$

${ }^{6}$ Agus Moh. Najib, "Hubungan Antar Agama", dalam Agus Moh. Najib dan Ahmad Baidowi (ed.), Merajut Perbedaan Membangun Kebersamaan (Yogyakarta: Dialogue Centre Press UIN, 2011), p. 47.

${ }^{7}$ Ahmad Syafi'i Ma'arif, Islam dalam Bingkai Keindonesiaan dan Kemanusiaan: Sebuah Refleksi Sejarah (Bandung: Mizan, 2015), p. 189.

${ }^{8}$ Muchlis M. Hanafi (ed.), al-Qur'an dan Isu-isu Kontemporer I (Tafsir al-Qur'an Tematik) (Jakarta: Lajnah Pentashih Mushaf al-Qur'an, 2012), p. 3. 
Various social conflicts occur usually not due to one factor as well, but because some of the factors that are related and intertwined each other. The religious leaders, government, and society undoubtedly take part and play an active role in efforts to conflict resolution and peace building, whether at the grassroots level within countries. ${ }^{\text {? }}$

As has been explained previously that all men are brothers because essentially the whole human being reunited on the same line that is sourced to Adam and Eve. Because of the distance and vulnerable such a long time till make the fraternity was unknown by many people. Brotherhood of humanity is a form of brotherhood which is not boxed the human being. From the elements and the diverse backgrounds, all are our brothers.

Fraternity Qur'an described is not only directed to the Muslims but also applies to all human beings, including the non-Muslims. Because the Qur'an explains that humans are all brothers and comes from one source, namely Adam mentioned in Q.S. al-Hujurat [45]: 13, Q.S. an-Nisa' [4]: 1, is also confirmed by some of the traditions of the Prophet as reported by Ahmad, Muslim, and Ibn Majah, and history that comes from Khuzaifah. Several Qur'anic verses such as Q.S. al-A'raf [7]: 189 and Q.S. az-Zumar [39]: 6 also testified that the man came from that one. While Q.S. Fatir [35]: 11, Q.S. Gafir [40]: 67, and Q.S. al-Mu'minun [23]: 12-14 describes the process through which a human creation. ${ }^{10}$ Therefore in Islam is known some of terms to bind the meaning of brotherhood, that brotherhood is not just a narrowly

${ }^{9}$ Ibid., p. 25.

${ }^{10}$ Look, Muchlis M. Hanafi (ed.), Hubungan Antar-Umat Beragama (Tafsir al-Qur'an Tematik) (Jakarta: Lajnah Pentashih Mushaf al-Qur'an, 2008), p. 51-54. 
conceived only in descent circle and religion but it has a very broad scope. ${ }^{11}$

In social life, we are not allowed to impose a variety of our will to others. There is no prohibition to do anything as long as it does not conflict with existing norms, and we are given the freedom to argue. Truth is believed by a group, not to become a tool to blame others even judgmental. Everyone even groups are certainly convinced of their each truth. Therefore, forcing others to follow the will and the way we are mistaken actions.

In this case, the prohibition of coercion needs to be interpreted more broadly, namely the prohibition of acts of violence in the name of religion. The destruction of places of worship of other religions is also not allowed. If coercion is forbidden, so it also applies to the destruction of houses of worship. Here, the verse has a wider impact in order to build a harmonious religious life and tolerant. ${ }^{12}$

Therefore, various forms of violence and social conflict that occurred in various regions in Indonesia lately, whether in political background, economic, ethnic even in religious, then the name of Islam is actually not a basic concept of Islam, and not to the teachings of Islam. Islam is a religion of peace and anti against all forms of violence and deeply appreciates the differences and diversity of society. ${ }^{13}$

We must relieve our ego which sometimes underestimate others even easy to trash and judge them by

${ }^{11}$ Fraternity or brotherhood in Islam is divided into ukbuwwah wataniyyah (brotherhood throughout the country), ukhumwah Is Tamiyyah (fellow Muslim brotherhood), and ukhuwwah basyariyah (brotherhood of humanity).

${ }_{12}$ Zuhairi Misrawi, Al-Quran Kitab Toleransi: Inklusivisme, Pluralisme, dan Multikulturalisme (Jakarta: Fitrah, 2007), p. 254.

${ }^{13}$ Sagaf S. Pettaalongi, "Islam dan Pendidikan Humanis dalam Resolusi Konflik Sosial", in Jurnal Cakrawala Pendidikan, No. 2, Juni 2013, p. 176. 
religious labels, such as heathen and perverted. ${ }^{14}$ Yet all still in process and walked toward a common point. The truth claim may only we hold, but do not let it blind us to see the others. Indonesia as a multicultural state will largely depend on how the Indonesian people take it. This situation can be brought on the line which makes nation's wealth and power, but can also be taken on the path that would be divisive and promoting conflict in society. ${ }^{15}$

Islam is a raḅmatan li al-áalamin religion (religion protects which all of nature). This concept implies a fairly comprehensive and provides space for all human community without regardless of social differences, because Islam sees the difference is a necessity. By this recognition, Islam gives respect for the diversity and encourage it to become an instrument inter fellow. ${ }^{16}$

We become one nation, not because we have only one same race, or the same tribe, or the same religion, or derived

${ }^{14}$ The emergence possibility of the seeds of discord in a multicultural society is very prone if multicultural communities faced the differences as a separator and causing our ego (the others are not part of us). People who lived thousands of years in multicultural by no means been immune to the possibility of friction ethnic, cultural, religious, social, political, and economic. Long experience of living in the difference was not enough to instill a sense of pride to be the difference and see it as a nation's wealth. Gina Lestari, "Bhinneka Tunggal Ika: Khasanah Multikultural Indonesia di Tengah Kehidupan SARA", in Jurnal Pendidikan Pancasila dan Kewarganegaraan, Tahun 28, No. 1, Februari 2015, p. 33.

${ }^{15}$ Gina Lestari, "Bhinneka Tunggal Ika: Khasanah Multikultural Indonesia di Tengah Kehidupan SARA", p. 33. As a country of multi-ethnic, cultural, and even religious, Indonesia should put the local culture and local wisdom proportionally. Differences between ethnic groups, cultures and religion should not be an element to crack the togetherness, otherwise become the legacy of complementary. Muchlis. M. Hanafi (ed.), Al-Qur'an dan Kebinekaan (Tafsir al-Qur'an Tematik), p. 230.

${ }^{16}$ Muhammad Ali Lintuhaseng, "Hak Asasi Manusia dalam Perspektif alQur'an", dalam Sahiron Syamsuddin (ed.), Studi al-Qur'an: Metode dan Konsep (Yogyakarta: eLSAQ Press, 2010), p. 101. Rights and obligations of religious communities in public life, among others: (a) the right to live in peace and security; (b) the right to be treated well; (c) the right to build houses of worship; (d) the right to equality and justice. Look, Muchlis M. Hanafi (ed.), Hubungan Antar-Umat Beragama (Tafsir al-Qur'an Tematik), p. 65- 100. 
from the same native country, or a pattern of the same culture. We became a nation which is created by the feeling of the sacrifices that we have made and experienced in the past together and we go through and experienced the present with the agreements that we made together, and further, we want to go through the future to continue to live together. ${ }^{17}$

\section{Humanities and Social Solidarity}

We are well aware that we are living in the reality of history and social reality is different. Our race, religion, nationality, even our ideology are different. That is therefore our life is colored with the diversity. But all these things will be a material susceptible of division and tension when there is no bonding and no unity. ${ }^{18}$

The peace would be realized if among people respect and regard each other. If the tolerance is lost, there will be no peace. According to the author, Tolerance and Peace are the two things that cannot be separated. Tolerance, which is the original nature of the natives, should be maintained. If there is a person that is destructive to the peace and tolerance in the society, it is an attempt to ruin the life of a nation. In this case, anyone who claims to believe in, and understanding, and has a conscience must have a big responsibility to designbuild paradigm of tolerance. Without this effort, tolerant life without violence will only be a dream. ${ }^{19}$

Indonesia with its diversity will certainly make some aspects of life become one. There is no specificity for certain groups. Social solidarity needs to be created, especially in

\footnotetext{
${ }^{17}$ Jimmy B. Oentoro, Indonesia Satu, Indonesia Beda, Indonesia Bisa, p. 8.

${ }^{18}$ Said Aqil Siroj, Islam Sumber Budaya Inspirasi Budaya Nusantara: Menuju Masyarakat Mutamaddin (Jakarta: LTNU, 2014), p. 257.

19 Zuhairi Misrawi, Al-Quran Kitab Toleransi: Inklusivisme, Pluralisme, dan Multikulturalisme, p. 179.
} 
social life, religion and state, because in daily life we certainly would require the participation and assistance of others.

Many different religions in Indonesia, including the existence of some other belief embraced by the Indonesian people do not make our lives be broken to pieces and fragmented. In religious life, the difference between one religion to another, does not need to be enlarged exaggerated and used as a tool to justify or attack the opposite with us. Differences rightly serve as a natural thing and not cause prolonged social problems. ${ }^{20}$ The most important thing is the right and duty to one another are present and in view of a difference, especially in a pluralistic religious life in Indonesia and mutual respect (tolerance) should be held by everyone. ${ }^{21}$

Therefore, man's nature as social beings which are harmony should provide guarantees for the realization of a life in harmony and peace. Religion and belief are not merely just a formality. No religion and belief system in the world that invites people to live in a tangled and anxiety atmosphere. They all told the followers to live in harmony, peace, and full of love among humans. ${ }^{22}$

The challenge which is faced in religious life in Indonesia is not narrow, because Indonesia also has high enough potential conflict. A joint responsibility of all stakeholders to cultivating an openness attitude, to accepting differences, and

${ }^{20}$ The difference that occurs is a fact that must be addressed in a positive way so that inter-religious happened human relations of mutual respect. Toto Suryana, "Konsep dan Aktualisasi Kerukunan Umat Beragama", Ta'lim: Jurnal Pendidikan Agama Islam, Vol. 9, No. 2, Tahun 2011, p. 135.

${ }^{21}$ Tolerance is needed to ensure the safe of the individual life, free-constructive issued a positive opinion, and the behavior of adherence to teachings and norms of positive community life. Dadan Rusmana dan Yayan Rahtikawati, Tafsir Ayat-ayat Sosial Budaya: Tafsir Maudhu'i terbadap Ayat-ayat al-Qur'an yang Berkaitan dengan Budaya, Sejarah, Babasa, dan Sastra (Bandung: Pustaka Setia, 2014), p. 292.

${ }^{22}$ Said Aqil Siroj, Tasawnf Sebagai Kritik Sosial: Mengedepankan Islam Sebagai Inspirasi, Bukan Aspirasi (Jakarta: SAS Foundation bekerja sama dengan LTN PBNU, 2012), p. 311. 
respecting for religious diversity, also accompanied by loyalty and commitment to their respective religions. Pluralism as a property owned by Indonesia, if directed on the positive will generate a positive thing. But, if the plurality is defined by narrow can cause divisions and disintegration as some cases that occur in some areas. An attitude that should be owned by the people of Indonesia not eliminate the existing pluralism, but should think and attempt to keep the social solidarity can be manifested So as to create peaceful coexistence, safe, tolerance, mutual respect and understanding of others. In internal Muslims do not deny there are also groups of different tendencies. A potential internal conflict in the Muslim is not smaller than the conflict between Muslims and people of other faiths. Therefore, the need for openness, respect each other's opinion and make a difference as a blessing and not as a trigger for conflict. ${ }^{23}$

Religions other than Islam also should get the same respect from the Islamic community. Places of worship, religious symbols sacred by other religions also have to be respected. Q.S. al-Hajj [22]: 40 states that tolerance in religious life can be realized if the mutual respect between the members included in beliefs. The Qur'an also forbids Muslims to commit acts of insult to the beliefs and symbols of the sanctity of other religions as mentioned in Q.S. alAn'am [6]: $108 .^{24}$

The concept also applies to non-Muslims against Muslims. Because many memorable discussion about tolerance more dominant when it comes to the relationship of Muslims to non-Muslims. Though true tolerance is

${ }^{23}$ Look, Abdurrahman, "Islam dan Pluralisme di Indonesia", dalam Sahiron Syamsuddin (ed.), Al-Qur'an dan Isu-isu Kontemporer (Yogyakarta: eLSAQ Press, 2011), p. 29-30.

${ }^{24}$ Look, Muchlis M. Hanafi (ed.), Hubungan Antar-Umat Beragama (Tafsir al-Qur'an Tematik), p. 32. 
common that is done by anyone. So when Muslims respect other religions, including how worship and the symbols of his faith, then other religions were already duly appreciate the trust of Muslims and respect the symbols sanctified by Muslims.

The believers are required to address religious teachings wisely and would be placed within the framework of complete understanding and reflects the substantial and universal teachings of their religion. Through that way, it will make others know that religion not as an enemy that must be resisted, with a comprehensive understanding of religious plurality of the human will to build tolerance among humans make communication and good cooperation in various aspects of life. ${ }^{25}$

Justification for ourselves and group not a few which ended with the dropping and deriding even blaspheming whom different with us. The difference is a matter that should be respected and appreciated. We certainly should not impose our will on others. We are given the right to express an opinion, but the opinions we received or performed by others were handed over to each person.

Islam is a religion of peace, in which there are values that teach an attitude of respect, respecting differences in beliefs and opinions. Religion of peace that is the essence of religious tolerance, good co-religionists, as well as inter- religious. ${ }^{26}$

Because the most important thing is how the diverse people live together and relate to each other without the p. 29 .

${ }^{25}$ Abd A’la, Melampani Dialog Agama (Jakarta: Penerbit Buku Kompas, 2002),

${ }^{26}$ Zainudin, "Dakwah Rabmatan lil-'Alamin: Kajian Tentang Toleransi Beragama dalam Surat al-Kafirun”, Jurnal Dakwah, Vol. X, No. 1, Januari-Juni 2009, p. 25. 
psychological barriers because of different religious and cultural understanding. ${ }^{27}$

In religious life and society, Muslims make the Charter of Medina ${ }^{28}$ as an example of the success of a concept of life that ever existed in the history of Islam that is applied by the Prophet who tied all elements of society from different backgrounds, then united in one vision. The values of this success can basically be applied to any religious life with respect for others, admits its existence, and gives rights and obligations.

Islamic sources such as the Koran and the Hadith explain the human rights that need to be maintained and protected by fellow society, nor the ruler. In addition, the theory of usul al-fiqh which is ad-daruriyyah al-khamsah reinforce that there are some things that had been duly maintained and protected because it is human rights that apply to all human beings regardless of their background. ${ }^{29}$

${ }^{27}$ Thoha Hamim, dkk. (ed.), Resolusi Konflik Islam Indonesia (Yogyakarta: IAIN Sunan Ampel, 2007), p. 125. Islam came not only aims to maintain its existence as a religion, but also acknowledges the existence of other religions, and gave him the right to live together while respecting the adherents of other religions. M. Quraish Shihab, Wawasan al-Qur'an: Tafsir Tematik atas Pelbagai Persoalan Umat (Bandung: Mizan, 2014), p. 498-499.

${ }^{28}$ The Medina is a social contract that is based on the concept of public agreement that consists of diverse ethnic which could live under one roof and one God. Charter also states the methods to solve all the problems between the ethnic groups and the diverse ethnic, in peace way without forced to embrace one religion, one language or culture. This reflects that the Prophet Muhammad had high diplomatic skills so as to form an alliance with all the practical considerations without neglecting the religious aspect. Zakiyuddin Baidhawy, "Piagam Madinah dan Pancasila: Prinsipprinsip Kehidupan Bersama dalam Berbangsa dan Bernegara", in Wawan Gunawan Abd. Wahid, dkk. (ed.), Fikih Kebinekaan: Pandangan Islam Indonesia Tentang Umat, Kewargaan, dan Kepemimpinan Non-Muslim (Bandung: Mizan Pustaka, 2015), p. 132.

${ }^{29}$ There are many verses and hadiths that mention of the rights of humanity that needs to be maintained and protected (Q.S. al-Baqarah [2]: 256), the right to freedom of religion (Q.S. al-Baqarah [2]: 279), the teachings of the equation (Q.S. al-Balad [90]: 13), and equality before the law (Q.S. al-Ma'idah [5]: 8). The Prophet also set the example in respect for human life, for example in the form of the Charter of Medina. The Prophet also sought a commitment in maintaining fairness and equality indiscriminately 
In view others, we should look at it from the standpoint of humanity, so social solidarity will be created even though we are different each other. Social and humanitarian solidarity will allow us to help each other when someone else was having problems or disaster regardless of what his status, religion, language, race or tribe, but the reason is because he is the man so we need to help them. Consciousness of humanity will eliminate social barriers that had been blanketed our life and paradigms of thinking.

The diversity which became the color of the people and the nation of Indonesia still able to show the unity, because of their cultural values that characterize our nation, namely the mutual assistance, kindship, discussion, tolerance, all of which strengthen the spirit of tolerance and harmony among peoples and our nations. ${ }^{30}$

as described in the hadith of Bukhari about the firmness of the Prophet, including when his daughter stole will be given the same law. The Prophet also did not consider the factor of ethnicity or group as a determinant of a person's glory but the benchmark is piety. From the verses of the Qur'an and the Hadith is then implemented in the theory of ușul al-figh which is ad-daruriyyah al-khamsab that includes five components, namely the protection of religion (ad-din), property (al-mál), life and human dignity (an -nafs wa al-ird), thinking (al-aqh), and descent (an-nash). These five components must be maintained by all elements of both individuals and groups, especially the community and the state. The concept also is not passive but active we are keeping the rights not only meets, but also as an obligation. Human rights that need to be maintained, among others: the rights of equality and freedom (Q.S. an-Nisa' [4]: 8, 107, 135; Q.S. al-Isra' [17]: 70; and Q.S. al-Mumtahanah [60]: 8); the right to life (Q.S. al-Ma'idah [5]: 45 and Q.S. al-Isra' [17]: 33); the right to obtain protection (Q.S. at-Tawbah [9]: 6, Q.S. al-Insan [76]: 8, and Q.S. al-Balad [90]: 12-17); the right to personal honor (Q.S. at-Tawbah [9]: 6); the right to marry and have a family (Q.S. al-Baqarah [2]: 221 and Q.S. at-Tahrim [66]: 6); the right to freedom of religion (Q.S. al-Baqarah [2]: 56, Q.S. al-Kahf [18]: 29, and Q.S. al-Kafirun [109]: 1-6); the right to work (Q.S. al-Baqarah [2]: 286, Q.S. at-Tawbah [9]: 105, and Q.S. al-Mulk [67]: 15); the right to freedom of action (Q.S. an-Nisa' [4]: 97 and Q.S. al-Mumtahanah [60]: 9); private property rights (Q.S. al-Baqarah [2]: 29 and Q.S. an-Nisa' [4]: 29); and the rights of detainees and prisoners (Q.S. al-Mumtahanah [60]: 8). Look, Ali Masykur Musa, Membumikan Islam Nusantara: Respons Islam terhadap Isuisu Aktual (Jakarta: Serambi Ilmu Semesta, 2014), p. 203-204.

${ }^{30}$ Weinata Sairin (ed.), Kerukunan Umat Beragama Pilar Utama Kerukunan Berbangsa: Butir-butir Pemikiran (Jakarta: Gunung Mulia, 2008), p. 14. 


\section{Diversity Education}

One sphere to keep Bhinneka Tunggal Ika can be maintained by linking it to education. Entering the realm of education, making the diversity can be poured in Diversity education which emphasizes the principles of multiculturalism. ${ }^{31}$

Multicultural concept that emphasizes equality and equal rights in the difference encourages educational institutions to apply a systematic and planned in educational practice because the paradigm of multicultural education will be able to build cohesiveness, solidarity and intimacy between the diversity of ethnicity, race, religion and culture. That is, if the multicultural values instilled early to children will help them to understand, accept and respect other people of different ethnic, cultural and personality value. Understanding of multicultural values is started from families, schools, and communities are expected to prevent friction between the personal and social intergroup which can lead to social conflict. Thus, everyone will realize that human beings are born with cultural backgrounds, customs, tribes, and religions. The difference is a necessity and it is sunatullah, natural law which must be received by everyone. Thus, there will be a sense of appreciation and treatment among fellow humanely, which is a model of treatment and interactions that always seen from the human side and the human values (humanism values)..$^{32}$

${ }^{31}$ Multicultural approach to education emphasizes that all cultures have a critical view of the truth. Respect for multiculturalism allows the creation of awareness coexist, while the diversity of cultures and beliefs form a dialectic paradigm, inclusive and pluralist. Muhammad Ali, Teologi Pluralis-Mutikultural: Menghargai Kemajemukan Menjalin Kebersamaan (Jakarta: Penerbit Buku Kompas, 2003), p. 165-166.

${ }^{32}$ Sagaf S. Pettaalongi, "Islam dan Pendidikan Humanis dalam Resolusi Konflik Sosial", p. 179. 
The idea of diversity in unity is very meaningful to Indonesian people, who live with national slogan "Bhinneka Tunggal Ika". That means that, although diverse, but still one. Tolerance does not occur easily and naturally. Tolerance should be pursued and further developed consciously, so that it becomes an important part in the social framework. Tolerance cannot grow in a indifference situation. Therefore, education is a must. In Indonesia became a requirement for each student from elementary to university to learn each religious education, so expect children can acquire sufficient education about their religion, and have sufficient knowledge about other religions, so as to create peace, harmony in difference. ${ }^{33}$

Therefore, education can be started from upstream, in family environment by respecting for the place of the older and loving the younger, respecting differences in background family members and respecting the opinions of others. Then in the scope of community/environment, by adapting and socializing with local communities, respecting the privacy of others, mutual assistance and respecting the differences which exist between each other. Diversity education, not only in elementary school, but Indonesian payload Bhinneka Tunggal Ika education remains a need to continue to be studied and deepened up to the level of Higher Education.

In the school environment, citizenship education may be regarded as a boring subject. However, civic education is an important thing, because it constitutes a payload which related to the pluralistic relationship of Indonesian society. Civic education needs to be presented and packaged more interesting for students to understand that Indonesia is a country that has a quite a lot population and have different

${ }^{33}$ Ali Maskur Musa, Membumikan Islam Nusantara: Respons Islam terbadap Isu-isu Aktual, p. 116. 
backgrounds. Therefore, is a necessity if in the end we will find the differences there. Thus, by understanding Bhinneka Tunggal Ika well will create an understanding and tolerance in students against others.

\section{Conclusion}

Diversity is a law of nature and is a gift for the nation of Indonesia which is not only to be grateful but also constantly cared for and maintained. The difference was essentially not being exaggerated because essentially we are all brothers. Therefore, it should be all elements of the nation without regard to certain groups must unite to achieve a better country and life of a prosperous society. By respecting, helping, opening each others, and dialogue if there is a problem occurs. To care for pluralism in Indonesia, education of Bhinneka Tunggal Ika need to be done early as persuasive and preventive measures. So early on our society has embedded understanding of the diversity of the nation but all remain united for the sake of a better Indonesia. 


\section{REFERENCES}

Abdurrahman. "Islam dan Pluralisme di Indonesia", in

Sahiron Syamsuddin (ed.). Al-Qur'an dan Isu-isu Kontemporer. Yogyakarta: eLSAQ Press, 2011.

A'la, Abd. Melampani Dialog Agama. Jakarta: Penerbit Buku Kompas, 2002.

Ali, Muhammad. Teologi Pluralis-Mutikultural: Menghargai Kemajemukan Menjalin Kebersamaan. Jakarta: Penerbit Buku Kompas, 2003.

Baidhawy, Zakiyuddin. "Piagam Madinah dan Pancasila: Prinsip-prinsip Kehidupan Bersama dalam Berbangsa dan Bernegara", in Wawan Gunawan Abd. Wahid, dkk. (ed.). Fikih Kebinekaan:Pandangan Islam Indonesia Tentang Umat, Kewargaan, dan Kepemimpinan Non-Muslim. Bandung: Mizan Pustaka, 2015.

Hamim, Thoha, dkk. (ed.). Resolusi Konflik Islam Indonesia. Yogyakarta: IAIN Sunan Ampel, 2007.

Hanafi, Muchlis M. (ed.). Al-Qur'an dan Isu-isu Kontemporer I (Tafsir al-Qur'an Tematik). Jakarta: Lajnah Pentashih Mushaf al-Qur'an, 2012. - Al-Qur'an dan Kebinekaan (Tafsir al-Qur'an Tematik).

Jakarta: Lajnah Pentashih Mushaf al-Qur'an, 2011. - Hubungan Antar-Umat Beragama (Tafsir al-Qur'an Tematik). Jakarta: Lajnah Pentashih Mushaf al-Qur'an, 2008.

Lestari, Gina. "Bhinneka Tunggal Ika: Khasanah Multikultural Indonesia di Tengah Kehidupan SARA", in Jurnal Pendidikan Pancasila dan Kewarganegaraan, Tahun 28, No. 1, Februari 2015. 
Lintuhaseng, Muhammad Ali. "Hak Asasi Manusia dalam Perpektif al-Qur'an", in Sahiron Syamsuddin (ed.). Studi al-Qur'an: Metode dan Konsep. Yogyakarta: eLSAQ Press, 2010.

Ma'arif, Ahmad Syafi'i. Islam dalam Bingkai Keindonesiaan dan Kemanusiaan: Sebuah Refleksi Sejarah. Bandung: Mizan, 2015.

Misrawi, Zuhairi. Al-Quran Kitab Toleransi: Inklusivisme, Pluralisme, dan Multikulturalisme. Jakarta: Fitrah, 2007.

Mujiburrahman. "Islam Multikultural: Hikmah, Tujuan, dan Keanekaragaman dalam Islam", in Addin Journal, Volume 7, Number 1, February 2013.

Musa, Ali Masykur. Membumikan Islam Nusantara: Respons Islam terhadap Isu-isu Aktual. Jakarta: Serambi Ilmu Semesta, 2014.

Najib, Agus Moh. "Hubungan Antar Agama Prespektif Syariah", in Merajut Perbedaan Membangun Kebersamaan, ed. Agus Moh. Najib and Ahmad Baidowi. Yogyakarta: Dialogue Centre Press, 2011.

Oentoro, Jimmy B. Indonesia Satu, Indonesia Beda, Indonesia Bisa. Jakarta: Gramedia Pustaka Utama, 2010.

Pettaalongi, Sagaf S. "Islam dan Pendidikan Humanis dalam Resolusi Konflik Sosial”, in Jurnal Cakrawala Pendidikan, No. 2, Juni 2013.

Rusmana, Dadan and Yayan Rahtikawati. Tafsir Ayat-ayat Sosial Budaya: Tafsir Maudhu'i terhadap Ayat-ayat alQur'an yang Berkaitan dengan Budaya, Sejarah, Bahasa, dan Sastra. Bandung: Pustaka Setia, 2014.

Sairin, Weinata (ed.). Kerukunan Umat Beragama Pilar Utama Kerukunan Berbangsa: Butir-butir Pemikiran. Jakarta: Gunung Mulia, 2008. 
Shihab, M. Quraish. Wawasan al-Qur'an: Tafsir Tematik atas Pelbagai Persoalan Umat. Bandung: Mizan, 2014.

Siroj, Said Aqil. Islam Sumber Budaya Inspirasi Budaya Nusantara: Menuju Masyarakat Mutamaddin. Jakarta: LTNU, 2014. - Tasawnf Sebagai Kritik Sosial: Mengedepankan Islam Sebagai Inspirasi, Bukan Aspirasi. Jakarta: SAS Foundation bekerja sama dengan LTN PBNU, 2012. Sujanto, Bedjo. Pemahaman Kembali Makna Bbinneka Tunggal Ika Persaudaraan dalam Kemajemukan. Jakarta: Sagung Seto, 2007.

Suryana, Toto. "Konsep dan Aktualisasi Kerukunan Umat Beragama", in Talim: Jurnal Pendidikan Agama Islam, Vol. 9, No. 2, Tahun 2011.

Zainudin. "Dakwah Rahmatan lil-Alamin: Kajian Tentang Toleransi Beragama dalam Surat al-Kafirun", in Jurnal Dakwah, Vol. X, No. 1, Januari-Juni 2009.

\section{Internet}

http:// m.tribunnews.com/nasional/2016/12/25/ menyedihkan-netizen-lecehkan-pahlawan-nasionaldari-papua-inilah-jasa-besarnya-untuk-indonesia, accessed 15 Januari 2017. 
Egi Sukma Baihaki

Halaman Ini Tidak Sengaja Untuk Dikosongkan. 